\title{
The initiation of an interest in the pulmonary circulation
}

\author{
W Whitaker
}

My association with Donald Heath began in 1953 when he started as a senior house officer at the Sheffield Regional Cardiovascular Centre based in the City General Hospital, now the Northern General Hospital. To appreciate the influence of these early days on Donald's career, which established him as a world authority on pulmonary vascular disease, it is helpful to look at the state of the art at that time and, in particular, at the developments taking place in Sheffield.

About 1950 James W Brown was appointed as consultant cardiologist to the Sheffield region, with the responsibility of developing a regional centre at the City General Hospital in Sheffield. James was a world figure in cardiology but had no experience of modern diagnostic methods. In Grimsby and Hull, with his contemporary, David Muir, James Brown pursued an interest in congenital heart disease, summarised in his book. ${ }^{1}$ No effective treatment for congenital heart disease was available until the 1940s when Blalock, Gaaford and Gross pioneered surgical treatment for patients with Fallot's tetralogy, coarctation of the aorta, and patent ductus arteriosus. These operations were introduced into the UK by Brock, Holmes-Sellars, Price-Thomas, and Tubbs. Without James Brown's backing there would have been probably no hypertensive pulmonary vascular disease story. Donald dedicated his MD thesis to James Brown.

I had been fortunate to obtain an appointment as a senior registrar in the Institute of Cardiology at the National Heart Hospital in London, where Paul Wood was the driving force. Wood published his observations in lectures on congenital heart disease in $1950 . .^{23}$ This is a wonderful illustration of the quality of the individual being of much greater importance than the expense of the equipment. Wood was a clinical master; he had said on a ward round that a clinician should have such confidence in his observations that he would be prepared to diagnose conditions which he previously did not know existed. There were about six training posts for registrars and senior registrars and it was Wood's intention to fill these with young postgraduates from the provinces and abroad, with the expectation that, when trained in clinical and investigative cardiology, they would return to their own regions to establish modern cardiological centres. When my training period in London was over I was offered a lectureship in medicine in Sheffield.

The Medical Professorial Unit in Sheffield, headed by Professor C H Stuart-Harris, was based at the Royal Hospital where there were two wards and restricted laboratory facilities.
In January 1951 I resuscitated cardiac catheterisation at the Royal Hospital and, during the next two years, investigated many patients with pulmonary and rheumatic heart disease. ${ }^{45}$

Stuart-Harris and James Brown had agreed that, rather than appoint a health service senior registrar to his research cardiological unit, he would have me to work with him. This was a promising venture since, not only did the Professorial Medical Unit and the Regional Cardiovascular Unit share wards, but our experiences were complementary. On the one hand there was James Brown - the pioneer of congenital cardiology in the UK but with no experience of modern cardiological investigations - faced with the problem of developing from scratch a modern diagnostic investigative cardiological service. On the other there was me with experience of cardiac catheterisation at the Royal Hospital, anxious to extend my expertise to patients with congenital heart disease. James had dozens of patients with obscure congenital anomalies who were investigated in Sheffield. Within a few weeks he produced seven patients with total anomalous pulmonary venous drainage. ${ }^{6}$ Donald came in later with a contribution to the series when one of these patients required a post mortem examination. ${ }^{7}$

In 1952 the investigative activities at the Royal Hospital were transferred to the new cardiac catheterisation suite at the City General Hospital where facilities for angiography had become established. The revolution in our investigations was the development of a spectrophotometric method for estimating blood oxygen saturations by Dr Mervyn Gattman, the lecturer in charge of the chemical laboratories of the Medical Professorial Unit at the Royal Hospital. This technique made redundant the tedious method of the Van Slyke blood gas analysis. Unfortunately he refused to publish his method before returning to his native New Zealand and was denied the credit he rightly deserved.

Within a few days of joining us Donald was taking an active part in, and had become responsible for, organising these investigations into congenital and acquired heart disease. $\mathrm{He}$ had the capacity to mobilise the team effectively but gently to a standard of perfection. Looking through my laboratory day books from the early 1950 s I am moved to find the minute to minute records of cardiac catheterisations and renal clearances in Donald's strong clear hand writing.

Donald was planning a career in clinical medicine and soon became a competent clinical cardiologist. He would carefully examine pa- 
tients on the wards, record his findings, and make a diagnosis or, at least, arrive at a differential diagnosis. Later when I did my ward round he would document my findings and clinical opinion in the notes in red ink, having provided himself with a special pen for this purpose. We would later have joint discussions when the results of laboratory studies and anatomical observations from operations or post mortem examinations were available, to see how these matched with our clinical observations.

I had nursed the idea of investigating the association between the pathology of pulmonary vascular disease and the abnormalities in pulmonary haemodynamics. Histological sections from the lungs of patients with pulmonary hypertension were scrutinised. Previously described abnormalities ${ }^{89}$ were seen. Lung biopsies in many patients with acquired and congenital heart disease who were being treated surgically would be justifiable as a prognostic indicator. This would enable correlation of the haemodynamics with the pathology of the pulmonary vascular bed. James Brown gave unqualified support to the project and Stuart-Harris agreed.

Donald's interest was immediate and enthusiastic; it was rather like lighting a fuse, sitting back, and watching the firework display. Donald saw William Evans in his Harley Street rooms. Evans warned him that if he was planning a career in research he would have to be prepared to starve. This advice obviously so influenced Donald that, since that time, one of his highest priorities has been to avoid starvation.

James Brown produced a constant succession of patients for investigation as candidates for surgical treatment. Every two or three months Donald and I would accompany Brown to Nottingham or Leicester where the local physicians and cardiac surgeons would present their cardiological patients as candidates for investigation in Sheffield. Material from these patients allowed us to investigate the relations between pulmonary hypertension and the anatomical changes in the pulmonary blood vessels - the main thrust of our research and the theme of Donald's MD thesis - and led to papers being published in the fournal of Pathology and Bacteriology and the British Heart fournal. ${ }^{10}$

There was a second string to our investigations. By correlating the clinical observations with the haemodynamic and angiographic and, when available, anatomical and histological findings, we were able to reassess the characteristics of many congenital anomalies including patent ductus arteriosus, ${ }^{11} \mathrm{Ei}$ senmenger's complex, ${ }^{5}$ ventricular septal defects, ${ }^{12}$ cardioaortic fistula, ${ }^{13}$ Ebstein's disease, ${ }^{14}$ tricuspid atresia, ${ }^{15}$ and idiopathic pulmonary hypertension. ${ }^{1617}$

Once Donald had his teeth into the pulmonary vascular disease project there was no doubt that it would be a success, but there was a minor problem of finding him a more permanent appointment. With support from Professor Wayne, James Brown persuaded the
Royal College of Physicians of London to appoint him a Leverhulme Research Scholar to work in the Sheffield Regional Cardiovascular Centre and with access to the University Department of Pathology.

Donald and I shared a room in the Regional Centre where we had a very efficient and happy production line; Donald would coordinate our efforts. One or two evenings a week he would come to my home, literally after tea. He would already have tables and illustrations immaculately prepared. He would sit at the dining room table with pen poised; there was no daydreaming or small talk; I was constantly urged to find the appropriate succinct phrases to express our views.

A memorable occasion from these early days was a symposium at Queen's College Dundee in September 1955. Dr Averil Liebow, Professor of Pathology at Yale, was visiting the University of St Andrews as Proelector and the Faculty of Medicine felt this was a unique opportunity to bring together physiologists, physicians, surgeons, and pathologists working within the pulmonary field. Donald was invited because of his important contribution to the work in Sheffield.

It is difficult to convey the excitement and electric atmosphere of those two days. I still look back on that Dundee meeting as one of the most important I have ever attended and I know that Donald, still in his twenties and attending his first national meeting, felt as if he were encountering deities.

Having launched the concept of hypertensive pulmonary vascular disease it seemed natural that we should publish our views. I remember clearly that we decided to do this as we were driving back from one of our visits to Nottingham, a week or two after the Dundee symposium. We agreed that there was a place for a review of the papers on the clinical and pathological features of pulmonary hypertension. We were spurred on by the knowledge that we would both soon be leaving Sheffield, Donald to a lectureship in Pathology in Birmingham and me to a Health Service appointment in Leeds. The article was offered to the Quarterly fournal of Medicine and, to our amazement, was rejected. This was our first and only rejection but, as events turned out, it was the best thing that could have happened for Donald's career. The script was submitted to Circulation. ${ }^{18}$ The paper was immediately accepted and read by a world audience of cardiologists and pathologists. It also gave Donald the opportunity to flaunt his MD for the first time in the press.

After its publication I was thrilled to receive a letter from Dr Jesse Edwards of the Mayo Clinic expressing an interest in our work. I replied to Dr Edwards telling of Donald's contribution to the pathological aspects of our joint papers and suggested that they should make contact. The outcome was that Donald obtained a Rockefeller Fellowship for 1957-58 to work with Jesse Edwards at the Mayo Clinic. This is the end of the Sheffield story; the rest is history. At the Mayo Clinic Edwards and 
Heath developed and elaborated the work started in Sheffield and produced a classification and grading of hypertensive pulmonary vascular disease which is now universally accepted.

I only met Dr Jesse Edwards on one occasion, at the World Congress of Cardiology in Brussels in 1958. I introduced myself and thanked him for accepting Donald as a Fellow at the Mayo Clinic. I forget his exact words, but Donald was obviously fresh in his mind when he replied that he was the one who should be thanking me, although he added that he had not realised that when he took on Donald he would be sacrificing two or three nights a week of his time to the production of their joint papers.

Several years ago at a medical meeting in Oxford I was approached by a South American postgraduate student who was, no doubt, aware of Donald's studies in the Andes. He asked me if I was the Dr Whitaker who had been Professor Heath's assistant. My immediate thought was to inform him of the proper historical hierarchical structure of the Heath-Whitaker relationship, but I desisted. I can think of nothing better than to be thought of as someone who was once of assistance to Donald Heath.
1 Brown JW. Congenital heart disease. Staples Press, 1939.

Wood PH. Congenital heart disease. A review of its clinica aspects in the light of experience gained by means of modern techniques. BMF 1950;2:639-45.

3 Wood PH. Congenital heart disease. A review of its clinical aspects in the light of experience gained by means of aspects in the light of experience gained by
modern techniques. Pt II. BMf 1950;2:693-8.

4 Whitaker W, Heath D, Brown JW. Patent ductus arteriosus with pulmonary hypertension. Br Heart f 1955;17:121-37. Brown JW, Heath D, Whitaker W. Eisenmenger's complex. Brown JW, Heath D, Whitake
Br Heart $\mathcal{f} 1955 ; 17: 273-84$.

6 Whitaker W. Total pulmonary venous drainage through persistent left super vena cavae. Br Heart $\mathcal{F} 1954 ; 16$. 177-88.

7 Heath D, Brown JW, Whitaker W. Total pulmonary venous drainage through a left superior vena cava. $\mathcal{7}$ Clin Pract 1956;10:692-7.

8 Brenner O. Pathology of the vessels of the pulmonary circulation. Pt. I. Arch Intern Med 1935;56:211-37.

9 Evans W. Congenital pulmonary hypertension. Proc $R$ Soc Med 1951;44:600-8.

10 Heath $\mathrm{D}$, Whitaker $\mathrm{W}$. The small pulmonary blood vessels in atrial septal defect. Br Heart f 1957;19:327-32.

11 Heath D, Whitaker W. Pulmonary vessels in patent ductus arteriosus. $\mathcal{F}$ Pathol Bacteriol 1955;70:285-90.

12 Heath D, Brown JW, Whitaker W. Muscular defects in the ventricular septum. Br Heart $\mathcal{f}$ 1956;18:1-7.

13 Brown JW, Heath D, Whitaker W. Cardioaortic fistula. A case diagnosed in life and treated surgically. Circulation 1955;12:819-26.

14 Brown JW, Heath D, Whitaker W. Ebstein's disease. $A m \mathcal{F}$ Med 1956;20:322-33.

15 Brown JW, Heath D, Moores TL, Whitaker W. Tricuspid atresia. Br Heart f 1956;18:499-518.

16 Heath D, Whitaker W, Brown JW. Idiopathic pulmonary hypertension. Br Heart $\mathcal{f} 1957 ; 19: 83-92$.

17 Whitaker W, Heath D. Idiopathic pulmonary hypertension: etiology, pathogenesis, diagnosis and treatment. Prog Cardiovasc Dis 1958;1:380-96.

18 Heath D, Whitaker W. Hypertensive pulmonary vascular disease. Circulation 1956;14:323-43. 